\title{
EDITORIAL
}

\section{Antipathy against SDD is justified: No}

\author{
Luciano Silvestri ${ }^{1,2}$, Hendrick K. F. van Saene ${ }^{3}$ and Julian Bion ${ }^{4^{*}}$
}

C 2018 Springer-Verlag GmbH Germany, part of Springer Nature and ESICM

Exam question: Which intervention targeted at preventing infection and mortality in critical illness has been evaluated positively in 71 randomised controlled trials over 35 years?

Well, of course you know the answer. Indeed, it is the wrong question to ask. The real question is why, given this body of research, has selective digestive decontamination (SDD) not been widely adopted, and why was it excluded from consideration by the most recent iteration of the international Surviving Sepsis Campaign (SSC) guidelines? We will try to unpackage this 'riddle wrapped in a mystery inside an enigma' [1].

SDD was excluded from the first iteration of the SSC guidance in 2004. Reasons offered at the time included the view that SDD was not a treatment for sepsis. The illogicality of this approach was immediately evident given the inclusion in the guidelines of prophylaxis for thromboembolic disease and for peptic ulcer disease. Following representations, SDD was included in 2008 and 2012. In 2008 the SSC adopted private polling to minimise bias, developing the 'GRADE grid' for that purpose [2]. This revealed two opinion groups: nine respondents weakly in favour and eight weakly opposed. Of the remaining participants, four were neutral, and one strongly opposed, giving SDD a $2 \mathrm{~B}$ rating (consider using the intervention). This rating was retained for the
2012 guidelines. However, in the most recent iteration in 2016 [3], SDD has been excluded without explanation, presumably being classed amongst a group of interventions of 'low importance and of low priority to clinicians'. If SDD is indeed of 'low priority', is this because of new and important scientific evidence demonstrating that it does not work, or because of deeply held but unfounded anxieties or antipathies? To assist with this analysis, we have summarised current evidence on the effect of SDD on mortality, infection, resistance and the microbiome in Table 1 (references in electronic supplementary material). This includes data from 71 randomised controlled trials, and confirms that SDD reduces mortality, reduces infections, reduces Gram-negative antimicrobial resistance, and does not promote Gram-positive infections. What other intervention in critical care medicine can match this record over 35 years of research?

Attitudes to SDD were explored in an international survey in 2013 of 141 participants which demonstrated substantial equipoise on risks and benefits of SDD, and expressed concerns that SDD might contribute to antimicrobial resistance [4]. A commonly expressed view is that it is wrong to give prophylactic enteral antimicrobials for long periods to critically ill patients to prevent infection; and yet the current approach of treating septic episodes with repeated and prolonged courses of parenteral 







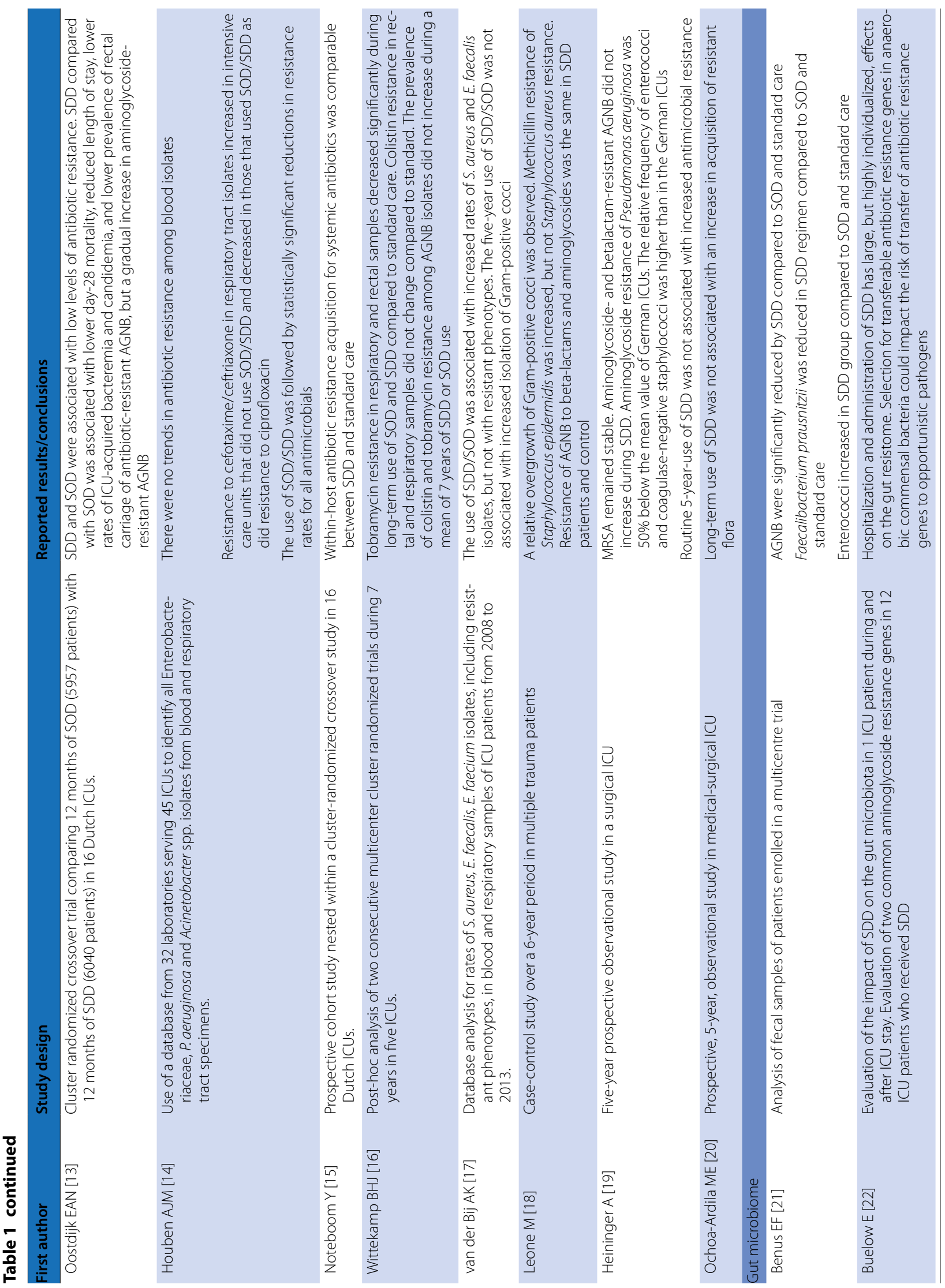




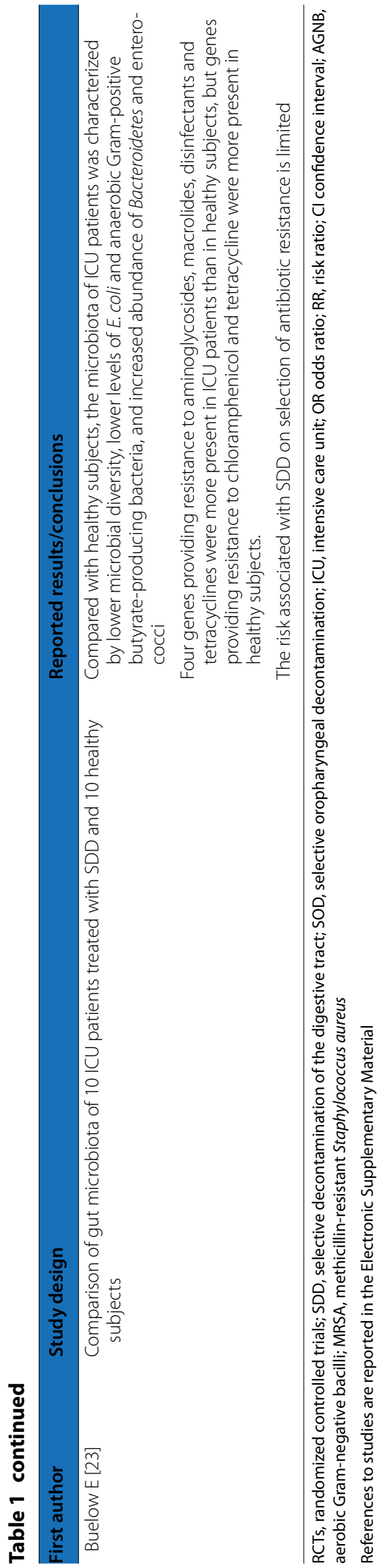

antimicrobials can hardly be described as a success from the perspective of antimicrobial resistance. By contrast, a systematic review in 2013 of resistance related to SDD found no relation between the use of SDD and antimicrobial resistance in ICU patients, and concluded that 'the perceived risk of long-term harm related to selective decontamination cannot be justified by available data' [5]. This conclusion was confirmed by a 4-year ecological study showing that the introduction of SDD in an ICU is associated with a significant reduction in resistance rates [6], and is reinforced by our summary of current research evidence (Table 1). Those who regard SDD as a resistance risk need to explain why ICUs in the Netherlands, where SDD is widely adopted, use fewer non-SDD antimicrobials and have a much reduced problem with antimicrobial resistance $[7,8]$ than those countries which rely predominantly on parenteral antimicrobials to prevent or treat nosocomial infections in critically ill patients.

As the traditional SDD regimen does not target MRSA and vancomycin-resistant enterococci, adjustment of the SDD medication by adding vancomycin should be considered in ICUs with a high endemicity of these Grampositive infections $[9,10]$. However, it should be noted that while some studies show an increase in Gram-positive isolates, a meta-analysis did not demonstrate an increase in Gram-positive infections [11].

The argument against SDD has now shifted to the microbiome. A recent study [12] reported the presence of numerous resistance genes in the gut microbiota of ten intensive care patients receiving SDD, compared with healthy individuals. But again, this is the wrong exam question. The real question is how does the gut microbiota of critically ill patients receiving SDD differ from those receiving only parenteral antimicrobials for nosocomial infection, and how do these two groups compare with hospitalised but not critically ill patients, and with a healthy population? Finally, how does the gut microbiota of surviving patients in the first two groups evolve following return to the community?

We hope that the answers to these focused questions might emerge from current research [13]. Researchers have struggled to obtain funding for further international collaborations evaluating SDD, perhaps because funders have noted the large evidence base which already exists in favour of the intervention. However, both the Australian and New Zealand Intensive Care Society (ANZICS) and the Canadian components of this study are now funded, and it is hoped that the UK will also be able to participate. If the SuDDICU study confirms (yet again) the benefits of SDD, then we should stop denying critically ill patients one of the few interventions in intensive care medicine which has been proven to be effective in saving lives and reducing harm. To those of our colleagues who 
regard SDD as being of 'low importance and of low priority to clinicians' [3], we feel justified to ask who it is they think they are treating-the clinicians, or our patients?

\section{Electronic supplementary material}

The online version of this article (https://doi.org/10.1007/s00134-018-5144-6) contains supplementary material, which is available to authorized users.

\section{Author details}

${ }^{1}$ Department of Anaesthesia and Intensive Care, St. John of God Hospital, Gorizia, Italy. ${ }^{2}$ Institute of Ageing and Chronic Disease, University of Liverpool, Liverpool, UK. ${ }^{3}$ Department of Musculoskeletal Biology, University of Liverpool, Liverpool, UK. ${ }^{4}$ Intensive Care Medicine, University of Birmingham, Birmingham, UK.

\section{Acknowledgements}

We thank Drs. Andy Petros, Hans J. Rommes, and Miguel A. de la Cal for their comments and for reviewing the manuscript.

\section{Compliance with ethical standards}

\section{Conflicts of interest}

The authors declare that they have no conflict of interest.

Received: 26 February 2018 Accepted: 17 March 2018

Published online: 7 June 2018

\section{References}

1. Churchill W. The Russian enigma. BBC broadcast, 1 October 1939

2. Jaeschke R, Guyatt GH, Dellinger P, Schünemann H, Levy MM, Kunz R, Norris S, Bion J, GRADE Working Group (2008) Use of GRADE grid to reach decisions on clinical practice guidelines when consensus is elusive. BMJ 337:a744. https://doi.org/10.1136/bmi.a744

3. Rhodes A, Evans LE, Alhazzani W, Levy MM, Antonelli M, Ferrer R, Kumar A, Sevransky JE, Sprung CL, Nunnally ME, Rochwerg B, Rubenfeld GD, Angus DC, Annane D, Beale RJ, Bellinghan GJ, Bernard GR, Chiche JD, Coopersmith C, De Backer DP, French CJ, Fujishima S, Gerlach H, Hidalgo JL, Hollenberg SM, Jones AE, Karnad DR, Kleinpell RM, Koh Y, Lisboa TC, Machado FR, Marini JJ, Marshall JC, Mazuski JE, McIntyre LA, McLean AS, Mehta S, Moreno RP, Myburgh J, Navalesi P, Nishida O, Osborn TM, Perner A, Plunkett CM, Ranieri M, Schorr CA, Seckel MA, Seymour CW, Shieh L, Shukri KA, Simpson SQ, Singer M, Thompson BT, Townsend SR, Van der Poll T, Vincent JL, Wiersinga WJ, Zimmerman JL, Dellinger RP (2017) Surviving Sepsis Campaign: international guidelines for management of sepsis and septic shock: 2016. Intensive Care Med 43:304-377. https:// doi.org/10.1007/s00134-017-4683-6
4. Cuthbertson BH, Campbell MK, MacLennan G, Duncan EM, Marshall AP, Wells EC, Prior ME, Todd L, Rose L, Seppelt IM, Bellingan G, Francis JJ (2013) Clinical stakeholders' opinions on the use of selective decontamination of the digestive tract in critically ill patients in intensive care units: an international Delphi study. Crit Care 17:R266. https://doi.org/10.1186/ cc13096

5. Daneman N, Sarwar S, Fowler RA, Cuthbertson BH, SuDDICU Canadian Study Group (2013) Effect of selective decontamination on antimicrobial resistance in intensive care units: a systematic review and metaanalysis. Lancet Infect Dis 13:328-341. https://doi.org/10.1016/s1473 -3099(12)70322-5

6. Houben AJ, Oostdijk EA, van der Voort PH, Monen JC, Bonten MJ, van der Bij AK et al (2014) Selective decontamination of the oropharynx and the digestive tract and antimicrobial resistance: a 4 year ecological study in 38 intensive care units in the Netherlands. J Antimicrob Chemother 69:797-804

7. de Smet AM, Kluytmans JA, Cooper BS, Mascini EM, Benus RF, van der Werf TS, van der Hoeven JG, Pickkers P, Bogaers-Hofman D, van der Meer NJ, Bernards AT, Kuijper EJ, Joore JC, Leverstein-van Hall MA, Bindels AJ, Jansz AR, Wesselink RM, de Jongh BM, Dennesen PJ, van Asselt GJ, te Velde LF, Frenay IH, Kaasjager K, Bosch FH, van Iterson M, Thijsen SF, Kluge GH, Pauw W, de Vries JW, Kaan JA, Arends JP, Aarts LP, Sturm PD, Harinck HI, Voss A, Uijtendaal EV, Blok HE, Thieme Groen ES, Pouw ME, Kalkman CJ Bonten MJ (2009) Decontamination of the digestive tract and oropharynx in ICU patients. N Engl J Med 360:20-31

8. Wittekamp BH, Oostdijk EA, de Smet AM, Bonten MJ (2015) Colistin and tobramycin resistance during long-term use of selective decontamination strategies in the intensive care unit: a post hoc analysis. Crit Care 19:113

9. de la Cal MA, Cerda E, Van Saene HK, Garcia-Hierro P, Negro E, Parra ML, Arias S, Ballestreros D (2004) Effectiveness and safety of enteral vancomycin to control endemicity of methicillin-resistant Staphylococcus aureus in a medical/surgical intensive care unit. J Hosp Infect 56:175-183

10. Silvestri L, Solidoro A, Milanese M, van Saene HKF, Fontana F, Gregori D, Gullo A (2010) Topical oropharyngeal vancomycin to control methicillinresistant Staphylococcus aureus lower airway infection in ventilated patients. Minerva Anestesiol 76:193-202

11. Silvestri L, van Saene HKF, Casarin A, Berlot G, Gullo A (2008) Impact of selective decontamination of the digestive tract on carriage and infection due to Gram-positive and Gram-negative bacteria. A systematic review of randomised controlled trials. Anaesth Intensive Care 36:324-338

12. Buelow E, Bello González TDJ, Fuentes S, de Steenhuijsen Piters WAA, Lahti L, Bayjanov JR, Majoor EAM, Braat JC, van Mourik MSM, Oostdijk EAN, Willems RJL, Bonten MJM, van Passel MWJ, Smidt H, van Schaik W (2017) Comparative gut microbiota and resistome profiling of intensive care patients receiving selective digestive tract decontamination and healthy subjects. Microbiome 5:88. https://doi.org/10.1186/s4016 8-017-0309-z

13. SuDDICU-ANZ (2015) A crossover, cluster randomised controlled trial of selective decontamination of the digestive tract in intensive care unit patients in Australian and New Zealand. https://clinicaltrials.gov/ct2/ show/NCT02389036. Accessed 22 Feb 2018 